\title{
Palestinian Refugees: H ost Countries, Legal Status and the Right of Return
}

\author{
W adie E. Said
}

\begin{abstract}
Given the Palestinian refugees' precarious legal status in their host countries, recognition of the Palestinian right of return is not only legally viable, but also crucial for the establishment of a just and lasting peace in the M iddle East. That racially driven demographic considerations have been employed up until now to derail binding and directly applicable laws and practices, as well as keep the refugees in a state of legal limbo in their host countries, cuts to the heart of the fundamental injustice currently plaguing the M iddle East. No amount of obfuscating the facts and the law can tarnish the applicability and relevance of the right of return, and Palestinian refugees and their advocates remain in both a strong moral and legal position to continue to call for the recognition of that right.
\end{abstract}

\section{Résumé}

Considérant la précarité du statut légal des réfu giés palestiniens dans leur pays hôte, la reconnaissance du D roit au retour des Palestiniens est non seulement légalement viable mais aussi un facteur essentiel pour qu'une paix juste et durable soit établie au M oyen Orient. L'usage d'inspi ration raciste - de facteurs démographiques pour faire échouer jusqu'à présent les lois et les pratiques exé cutoires directement applicables et ainsi maintenir les ré fugiés dans un état juridique incertain dans leur pays hôte, est au cœur de l'injustice fondamentale qui empoisonnela situation au M oyen-Orient. Toutes les tentatives en vue d'obscurcir les faits et la loi n'arriveront jamais à ternir l'applicabilité et la pertinence du Droit au retour. Les Palestiniens et leurs défenseurs restent donc en position forte, aussi bien au plan moral quelé gal, pour continuer leur revendication pour la reconnaissance de ce Droit.
$\mathrm{P}$ alestinians, like I sraelis, want a national existence. On this both Yasser Arafat and those Palestinians who opposeA rafat agree. But Pal estiniansare, in themain, refugees who long for repatriation - the right of return. These are fighting words, both between Israelis and Palestinians and, in certain cases, between Palestinian and Palestinian. Accordingly, it is best to begin slowly, to go over again the situation which has brought us where we are today.

In 1948, as a result of the first Arab-Israeli war, approximately 750,000 out of an estimated 900,000 Palestinian Arabs who were then living in the area that now comprises the state of I srael - which was, in turn, some 77 per cent of the area of Palestine as established by the 1922 League of Nation Mandate - were driven from their homes. ${ }^{1}$ The remaining 23 per cent of $M$ andatory Palestine was apportioned between Jordan, which took control of the area now known as the West Bank, and Egypt, which took control of the Gaza Strip. ${ }^{2}$ Of those 750,000 who were displaced, approximately 360,000 fled to theW est Bank, 200,000 went to the Gaza Strip, 110,000 fled to Lebanon, 100,000 went to Jordan (the East Bank), and 82,000 went to Syria. ${ }^{3}$ Smaller numbers of refugees made their way into Egypt proper.

Thosenumbers havenow grown considerably. Thereare currently some 3.97 million refugees from Pal estine registered with theU nited Nations: 1,679,623 in Jordan, 878,977 in the Gaza Strip, 626,532 in the West Bank, 401,185 in Syria, and 387,043 in Lebanon, according to themost recent figures. ${ }^{4} \mathrm{An}$ additional 1.5 million Palestinian refugees are not registered with the $U$ nited Nations. ${ }^{5}$

The official Israeli position is that the Palestinians fled of their own accord in 1948 and consequently Israel has no obligation to repatriate them. ${ }^{6} \mathrm{H}$ owever, "revisionist" historians, both Palestinian and Israeli, have debunked the theory that theArab states wereresponsiblefor therefugees' flight. ${ }^{7}$ Archival research has revealed that the expulsion of the Pal estinians was an explicit goal of leaders of the Yishuv, 
the Jewish community in Palestine - David Ben-Gurion, M oshe D ayan, and Yitzhak Rabin. ${ }^{8}$ The only real scholarly debate now is whether the ethnic cleansing of that part of Palestine that became Israel was deliberate or merely the result of battlefield decisions. ${ }^{9}$ That the Pal estinians were made refugees as a result of Israeli military action is no longer really debatable.

To ensure basic levels of carefor thePal estinians, the UN in 1949 created UNRW A, the U nited N ations Relief W orks A gency for the Pal estine Refugees. ${ }^{10}$ I ts task was, and still is, to "prevent conditions of starvation and distress among [the refugees] and to further conditions of peace and stability,... [C]onstructive measures should be undertaken at an early date with a view to the termination of international assistance for relief." 11 To this day, UNRWA operates the majority of recognized refugee camps, while continuing to provide essential education, health, relief, and social services to Palestine refugees in Lebanon, Syria, Jordan, the W est Bank, and the Gaza Strip..$^{12}$ I ronically, since the refugees are considered to be "at present receiving [protection and assistance] from organs or agencies of the U nited Nations other than the U nited Nations High Commission for Refugees," namely UNWRA, the Palestinians are not subject to the protections and safeguards of the 1951 Convention Relating to the Status of Refugees or the 1967 Protocol Relating to the Status of Refugees. ${ }^{13}$ W hile some scholars and advocates have argued that the Refugee Convention and Protocol, along with other international agreements concerning stateless persons, should apply to the Palestinians and that they should receive the protection of $\mathrm{UNHCR}$, that position has yet to be put into practice. ${ }^{14}$ The ostensiblereasoning behind this policy choice, onethat enjoys at least somesupport from thePal estiniansthemselves, is that the Palestinian refugees, unlike most refugees around the world, seek repatriation only and not the option of asylum in a third country. ${ }^{15}$ W hile there are strong arguments in favour of allowing Palestinians to enjoy the rights and benefits of these international treaties, most notably the right to represent themselves (as opposed to being represented by the Palestine Authority created for them by other nations) in any negotiations on their final status, it seems as if the current legal predicament of the Palestinian refugees vis-à-vis the UN will not change in the foreseeable future.

With respect to the legal status of Palestinian refugees, each region in which refugees currently reside presents a different picture. Refugees in the W est Bank and Gaza Strip enjoy the same legal rights as do the non-refugee Palestinian population, except that refugees in the W est Bank are eligi ble for Jordanian passports, but those passports are for travel purposes only and do not confer Jordanian citi- zenship. ${ }^{16}$ Thus, the holder can be refused entry by Jordan as by any other country in the world under each nation's immigration laws and policies. Refugees in both the West Bank and Gaza Strip are also eligible for a passport issued by the Palestinian Authority, but are permitted to travel on it only if I srael has granted permission, since Israel retained control over borders under the terms of the 0 slo accords. ${ }^{17}$ West Bank refugees traveling on a Palestinian Authority passport may also lose the right to Jordanian citizenship - a policy adopted by Jordan in 1995.18 For everyday purposes, West Bank and the Gaza Strip refugees hold identity cards issued by the Palestinian Authority that also display the number of the holder's previous Israeli-issued identity card.

Around 1.68 million refugees reside currently in Jordan, a figure that represents some 42 per cent of the Palestinian refugees registered with UNRWA.19 In addition, there are in Jordan an estimated 800,000 refugees who were displaced in 1967, when they fled the Israeli army'sadvance on the W est Bank. ${ }^{20}$ Of the total figure, around 293,000 live in refugee camps, amounting to no more than 17 per cent of the total Palestinian refugee population of Jordan. ${ }^{21}$ The remaining 82 per cent live outside the camps. All Jordanian refugees whether living in or outside camps enjoy the beneits of full Jordanian citizenship, including the right to vote. ${ }^{22}$ H owever, a recent book by Joseph $M$ assad, a professor of political science at Columbia University, details, among other things, the discrimination Palestinians in Jordan suffer, especially in regard to employment in the public sector and representation in government. ${ }^{23}$ In addition some 150,000 refugees who made their way to Jordan following the 1967 war from the Gaza Strip do not enjoy full citizenship in Jordan and cannot vote or hold jobs in thepublic sector. ${ }^{24}$ These Gaza Strip refugees are eligible to travel on Jordanian passports that are only valid for two years, as opposed to the standard five years. ${ }^{25} \mathrm{~W}$ ere the Palestinian refugees in Jordan covered by the 1951 Refugee Convention or the 1967 Protocol - which they are not because of their protection under UNWRA - they would losetheir designation as "refugees" by virtue of accepting citizenship in J ordan. ${ }^{26} \mathrm{H}$ owever, the fact that refugees in J ordan become Jordanian citizens does not terminate their refugee status under UNRWA regulations. ${ }^{27}$ As a result they continue to be entitled to return to the lands from which they were driven and to receive compensation for their dispossession.

W ith respect to Syria, out of the 401,000 Palestinian refugees, around 116,000 currently live in UNRWArecognized refugee camps. ${ }^{28}$ In general, Pal estinians enjoy many of the same rights as Syrian citizens, although they are not eligible for Syrian citizenship. ${ }^{29}$ They enjoy equal rights in labour and employment, where they are allowed 
to work and join trade unions. ${ }^{30}$ They are allowed to own more than one business or commercial enterprise. ${ }^{31}$ They are also allowed to serve in the Syrian military. ${ }^{32}$ Palestinians can move freely within Syria and are not limited in where they can reside within the country. ${ }^{33}$ Palestinian refugees can leave and re-enter Syria on a government issued travel document or laissez-passer. ${ }^{34}$ By way of contrast, the 50,000 or so Palestinian refugees currently residing in Egypt are not allowed to leave the country without first obtaining a return visa, which is issued at thediscretion of the Egyptian authorities. ${ }^{35}$ Palestinians in Syria cannot own more than one home, however, and cannot purchase arable land ${ }^{36} \mathrm{~N}$ or can the refugees in Syria vote in parliamentary or presidential elections or run as candidates for political office. ${ }^{37}$

In Lebanon the situation of Palestinian refugees is the most grave. Fifty-six percent of the total of 387,000 Palestinian refugees in Lebanon live in the twelve refugeecamps run and recognized by UNRWA ${ }^{38}$ Over 75,000 other refugees live in unrecognized camps or temporary shelters, bringing the total percentage of refugeesliving in camp-like dwellings to 75 per cent of the refugee population. ${ }^{39}$ The Department of Affairs of the Palestinian Refugees, an office within the Lebanese M inistry of the Interior, is responsible for administering the Palestinian presence in Lebanon..$^{40} \mathrm{All}$ births, deaths, and marriages must be registered with the Department, which also must approve any changes in residence. ${ }^{41}$ The Department decides whether or not to issue travel documents for the refugees and must approve financial aid transferred to them from abroad. ${ }^{42}$ The Department maintains a profile on each refugee and assesses for the $M$ inistry the security risk the refugee may pose. ${ }^{43}$

Palestinians are classified as foreigners in Lebanon and may not work without a work permit, which is rarely granted except in a few limited sectors. ${ }^{44}$ The vast majority of Palestinian refugees in Lebanon can only work in UNRWA, the Palestinian Red Crescent Society, NGOs, or unsteady, low-paying, dangerous, and unregulated work, primarily in construction and seasonal agriculture. ${ }^{45}$ Palestinians are excluded from certain professions. To beadmitted to the Lebanese Bar or to obtain work in a government agency, a person must have been a Lebanese citizen for at least ten years. ${ }^{46}$ Even with a work permit Palestinian refugees remain ineligible for social service benefits, although deductions aremadefor such benefits from their pay. ${ }^{47} \mathrm{~N}$ or may the Palestinian refugees join trade unions as fullfledged members or officers. ${ }^{48}$ Finally, last year the Lebanese government passed a law decreeing that Palestinians could not own real property. ${ }^{49}$ In short, Lebanon is in gross violation of its obligations under both the International Covenant on Economic, Social and Cultural Rights and the
International Convention on the Elimination of All Forms of Racial Discrimination, each of which guarantees theright of work, the right to form and join trade unions, and the right to receive social services and benefits on the same terms as a country's citizens. ${ }^{50}$

The legal situation of the Palestinian refugees in Lebanon explainsin part why an estimated 80 per cent live in poverty. ${ }^{51}$ Other factors include the elimination of the Gulf countries as a source of potential employment, as a result of thePLO's siding with Iraq, and, ironically, the PLO's cessation of most forms of aid to Jordanian refugees following the signing of the Oslo Accords in September 1993..$^{22}$ In this connection, a high-ranking Palestinian Authority M inister remarked in March 1995 that the Palestinians in Lebanon should be considered the responsibility of UNRWA, which has concentrated its aid on the W est Bank and Gaza. ${ }^{53}$ The risein poverty has al so created a health crisis, as Palestinians are not allowed access to Lebanese government hospitals and other health services. ${ }^{54}$ Official and unofficial hostility to Palestinians runs high in Lebanon, with one minister referring to them in 1995 as "human waste." 55

Essentially, the only real, long-term, solution to the Arab-Israeli conflict is to solve the refugee issue. Resettlement in countries bordering Israel, the West Bank, and Gaza will only seethe refugeesituation shunted off onto the host countries, the refugee populations of which naturally will never settle in knowing that the country that displaced them borders their country of resettlement. ${ }^{56}$ It is only within this context that one can begin to understand the right of return - that is, the right of the refugees to return to the areas of their origin which are now within the state of I srael - a right that has broad support both within the Arab world and among refugees. Currently, Israel refuses to allow thePalestinian refugeesto return, except within the narrowly limited confines of family reunification, while at the same time allowing every person meeting I srael's definition of a Jew, regardless of country of birth, to immigrate and obtain citizenship in Israel based on [the] Law of Return, passed by the Knesset in $1950 .{ }^{57}$ The legal basis of the Palestinian right of return is not in any doubt and derives from several independent but mutually enforcing sources of international law..$^{58}$ Article 11 of UN General Assembly Resolution 194, ratified on December 11, 1948, states that:

...therefugees wishing to return to their homes and livein peace with their neighbors should bepermitted to do so at the earliest practicable date, and that compensation should be paid for the property of those choosing not to return and for the loss of or damageto property which, under theprinciples of international 
law or in equity, should be made good by the Governments or authorities responsible. $^{59}$

This resolution has been reaffirmed by the General Assembly every year sinceits passage. ${ }^{60}$ The resolution also created the Conciliation Commission for Palestine, which was directed to "facilitate" implementation of the Palestinian right of return. ${ }^{61} \mathrm{H}$ owever, the Conciliation Commission ceased all efforts to repatriatePal estinian refugees in 1952, stymied by the conflicting positions of the Arab states and I srael. ${ }^{62}$ The former demanded full repatriation, while the latter refused any attempts at repatriation in any degree. Nevertheless, GA Resolution 194 remains as valid today as it was in 1948 and later resolutions reaffirm "the inalienable right of the Palestinians to return to their homes and property from which they have been displaced and uprooted, and calls for their return." ${ }^{63}$ Additionally, it should be noted that Israel's admission to the United Nations in GA Resolution 273 of 1949 was conditioned upon its full implementation of the provisions of Resolution $194{ }^{64}$

The principle of the right of return has been upheld by none other than former U.S. President Bill Clinton, who stated on A pril 5, 1999, in referring to the Kosovar refugees and a final peace settlement, that: "The refugees belong in their own homes, in their own land." ${ }^{65}$ Clinton added that: "O ur immediate goal is to providerelief; our long-term goal is to give them their right to return." ${ }^{66}$ In another context, in 1996, the European Court of Human Rights ruled, in a case involving a Greek Cypriot woman who had been dispossessed following the 1974 invasion and occupation of part of Cyprus by the Turkish army - an occupation that saw 200,000 Greek Cypriots made refugees who are, incidentally, still waiting to return - that she remained the rightful owner of her property and was entitled to compensation for its use for the period of its occupation. ${ }^{67} \mathrm{~A}$ subsequent decision by that same court found that the refusal to allow the return of any Greek-Cypriot displaced persons to their homes in northern Cyprus represented a violation by T urkey of theEuropean Convention on H uman Rights. ${ }^{68}$ Finally, numerous peace accords over the last twenty years, covering conflicts from Bosnia to Indochina to Guatemala and El Salvador, have affirmed the property rights of refugees and, of course, their right of return. ${ }^{69}$

The principle of a right of return for displaced refugees is also found in international humanitarian law, which governs the conduct of states during war and occupation. The Fourth Geneva Convention of 1949 states that "[i]ndividual or mass forcible transfers, as well as deportations of protected persons from occupied territory to the territory of the Occupying power or to that of any other country, occupied or not, are prohibited, regardless of their mo- tive." 70 The Universal Declaration of H uman Rights states that "[ e]veryone has the right to leave any country, including his own, and return to his own country," and that "[n]o one should be arbitrarily deprived of his own property." 71

Current Israeli opposition to the right of return is based not on legal but on demographic and, to be blunt, ethnic bias. Two arguments are advanced here. First, the claim is sometimes made that the areas currently comprising the state of Israel cannot possibly support the influx of large numbers of Pal estinian refugees. A study of the demography of Israel shows that 78 per cent of Israel is are living in 14 per cent of Israel and that the bulk of the refugees fled from the remaining 86 per cent of the land in Israel on which only 22 per cent of Israelis live. ${ }^{72}$ Incidentally, the total number of refugees from Gaza and Lebanon is more or less equal to the total number of immigrants from the former Soviet Union who came to Israel starting in thelate 1980 s to live in the refugees' homes and/or on their lands and elsewhere within Israel. ${ }^{73}$

Somealso arguethat if the Pal estinian refugees are allowed to return to Israel, then the ewish nature of the state would be altered. ${ }^{74}$ Leaving to one side the paradox that in the Jewish state of Israel over 20 per cent of its citizens are non-J ews, demographic concerns are entirely premature at this stage, given that I srael shows no signs of accepting the right of return and that the exact number of refugees wanting to return is unknown at this time. Regardless, the natureand universal acceptance of the principle of the right of return should trump any demographic considerations, especially those rooted in racial discrimination and nothing more. In any event, what exempts Israel from being held accountableunder international legal norms and standards for a refugee population it clearly created? As one study on this subject has noted, "[ $\mathrm{t}$ ]he U nited N ations is under no more of a legal obligation to maintain Zionism in Israel than it is to maintain apartheid in South Africa." 75 W ith respect to the anti-Arab bias behind Israel's invocation of an ethnically pure Jewish state, suffice it to note that the process of encouraging immigration from the former Soviet U nion has resulted in at least 200,000 - and possibly as many as 400,000 - non-Jews from that region settling in Israel. 76

Currently, as is now well known, not only Israel but also the Palestinian Authority are the chief opponents of the Palestinian right of return. The 0 slo Agreements deal only with the aftermath of the 1967 and 1973 Arab-I sraeli wars and do not so much as mention General Assembly Resolution $194 .{ }^{77}$ Yasser A rafat himself, in a N ew Y ork Timesop-ed article, called for a settlement of therefugeeissuethat would 
eliminate Israel's demographic concerns. ${ }^{78}$ Theformer PLO representative in Jerusalem, Sari N usseibeh, has called on Pal estinians to give up the right of return in order to seethe goal of a Palestinian state in the West Bank and Gaza realized and has worked out a proposed peace plan with former Israeli Shin Bet chief Ami Ayalon that reflects that position. ${ }^{79}$ In September 2002, the Israeli daily Ha'aretz reported the PLO executive committee member Abu M azen had give a speech at a refugee camp in Syria in which he intimated that the refugees should give up calling for their right of return. ${ }^{80} \mathrm{~T}$ hemost recent reports havethesameA bu Mazen commenting on a draft peace plan that gives only "lip service" to the right of return and guarantees that Israel's demographic balance will not be upset..$^{81}$ Further, news of a draft Palestinian constitution currently in the works reveals that the language contemplated does not refer to a mass return of refugees, a position that is likely to meet with I srael's favour. ${ }^{82}$ Not surprisingly, the I sraeli government and press agree: the total elimination of the Palestinian right of return is non-negotiable.

Given the Palestinian refugees' precarious legal status in their host countries, it should be therefore clear that a recognition of their right of return is not only legally viable, but also crucial for the establishment of a just and lasting peace in the M iddle East. That racially driven demographic considerations have been employed up until now to derail binding and directly applicable laws and practices, as well as keep the refugees in a state of legal limbo in their host countries, cuts to the heart of the fundamental injustice currently plaguing the M iddle East. No amount of obfuscating the facts and the law can tarnish the applicability and relevance of the right of return, and Palestinian refugees and their advocates remain in both astrong moral and legal position to continue to call for the recognition of that right.

\section{Notes}

1. D. Hirst, The Gun and the Olive Branch (Harcourt: 1977) at 142; N. M asal ha, A Land without a People: Israel, Transfer and the Palestinians 1949-96 (London: Faber \& Faber, 1997) at xi.

2. S.K. Farsoun \& C.E. Zacharia, Palestine and the Palestinians (Boulder, Colo: Westview Press, 1997) at 123-27.

3. Id.

4. UNRWA in Figures as of June 30, 2002, available online: <http://www.un.org/unrwa/pr/pdf/uif-june02.pdf > (date accessed: 10 February 2003).

5. "Questions \& Answers ( $\& A$ ): Palestinian Refugees," available online: <http://www.badil.org/Refugees/Answers/questions_and_answer s.htm> (date accessed: 10 February 2003).

6. B. Morris, The Birth of the Palestinian Refugee Problem, 1947-49 (N ew York: Cambridge University Press, 1987) at 1.

7. Id.; I. Pappe, The Making of the Arab-Israeli Conflict, 1947- 1951 (N ew York: St. M artin's Press, 1992).
8. Id.

9. Id.

10. GA Res. 302 , UN GAOR, $4^{\text {th }}$ Sess., UN Doc. A/1251 (1949).

11. Id.

12. UNRWA web page, online: <http://www.un.org/unrwa/ about/index.html> (date accessed: 27 N ovember 2002).

13. Convention Relating to the Status of Refugees, 28 July 1951 , art.1(D), 189 U.N.T.S. 150, 137.

14. See, e.g., S. Akram, "Palestinian Refugees and Their Legal Status: Rights, Politics, and Implications for a Just Solution" (Spring 2002) J. Pal estine Stud. 36-51.

15. GA Res. 428(V), Annex: "Statute of the Office of the U nited N ations High Commissioner of Refugees."

16. U. S. Committee for Refugees, "Country Report: Jordan," available online: <http://www.refugees.org/world/countryrpt/mideast/Jordan.ht $\mathrm{m}>$ (date accessed: 10 February 2003).

17. Israeli-Palestinian Interim Agreement on the West Bank and Gaza Strip, art. XXVI(1) 28 September 1995.

18. Supra note 16.

19. Supra note 4.

20. Supra note 16.

21. Supra note 4.

22. Supra note 16.

23. J. M assad, Colonial Effects: The $M$ aking of $N$ ational Identity in Jordan (N ew York: Columbia University Press, 2001).

24. Supra note 16.

25. Id.

26. Id.

27. Id.

28. Supra note 4.

29. U.S. Committee for Refugees, "Country Report: Syria," available online: <http://www.refugees.org/world/countryrpt/ mideast/Syria.htm > (date accessed: 10 February 2003).

30. N.M. as-Sahly, "Profiles: Palestinian Refugees in Syria" M ajdal, (December 1999), available online: <http://www.badil. org/Publications/M ajdal/1999/4_12.htm> (date accessed: 10 February 2003).

31. Id.

32. Id.

33. Id.

34. Id.

35. A. Shiblak, Residency Status and Civil Rights of Palestinian Refugees in Arab Countries (monograph) at III, available online: <http://www.shaml.org/publications/monos/monol. htm > (date accessed: 10 February 2003).

36. Supra note 30.

37. Id.

38. Supra note 4.

39. M. Abbas, "The Socio-Economic Conditions of the Palestinians in Lebanon: The Housing Situation of the Pal estinians in Lebanon" (1997) 10 J. Refugee Stud. 379 at 380-81.

40. Al-Marsoum Al-Ishtirai' [Legislative Decree] No. 42 (1959) (Leb.); Legislative Decree N o. 927 (1959) (Leb.); seealso W .E. Said, "The Pal estinians in Lebanon: The Rights of the Victims 
of the Palestinian-Israeli Peace Process" (1999) 30 Colum. H um. Rts. L. Rev 315 at 325-27 for a moredetailed discussion of this topic.

41. Id.

42. Id.

43. Id.

44. Law Pertaining to the Entry Into, Residence In and Exit From Lebanon, art. 1 at 2 (1962) (Leb.) (classifying Palestinian refugees as foreigners by omission); Lebanese Law N $0.87 / 25$, art. 1§2, 6/18/1987; Decree No. 17561 Regulating Foreigner Work, art. 11-14 at 22-23 (Leb.).

45. H. Shaaban, "Unemployment and Its I mpact on the Palestinian Refugees in Lebanon" (1997) 10 J. Refugee Stud. 384 at 385-86.

46. Souheil Al-Natour, awDa' ash-Sha'b al-Filastini fi Lubnan [The Predicament of the Palestinian People in Lebanon] 125 (1993); Legislative Decree No. 112 (1959), in S. Abi-Nader, ed., $6 \mathrm{M}$ ajmu'at at-Tashri' al-Lubnani [Anthology of Lebanese Legislation], 1.

47. Social Security Law, art. 9, I 4 in Q anun aD-Daman al-Ijtimai' wa Qanun Tasheel al-Iskan fi Lubnan [The Social Security Law and the Housing Facilitation Law in Lebanon] 13-14 (compiled and edited by Iskandar Saqr).

48. Qanun al-Amal al-Lubnani [Lebanese Labor Law], arts. 91, 92, reprinted in S. Abi-Nader, ed., 4 Majmua'at at-Tashri' al-Lubnani (1962) 1.

49. U.S. Committee for Refugees, "Country Report: Lebanon," available online: <http://www.refugees.org/world/countryrpt/ mideast/lebanon.htm> (date accessed: 10 February 2003).

50. See generally Said, supra note 40 at 329-41 for a lengthier discussion of Lebanon's dereliction of its duties to Palestinian refugees under international law.

51. Shaaban, supra note 45 at 387.

52. R. Sayigh, Too M any Enemies: The Palestinian Experience in Lebanon (London: Zed Books, 1994) at 326.

53. R. Sayigh, "Palestiniansin Lebanon: Harsh Present, Uncertain Future" (Autumn 1995) J. Palestine Stud. at 41 ("At U NRW A'semergency meeting last $M$ arch [1995], PA delegate $\mathrm{N}$ abil Shaath stated emphatically that Pal estinians in Lebanon were not the PA's responsibility but UNRWA's").

54. Id. at 44; Y. Besson, "UN RWA and ItsRolein Lebanon” (1997) $10 \mathrm{~J}$. Refugee Stud. 335 at 339.

55. F. Nasrallah, "Lebanese Perceptions of the Palestinians in Lebanon: Case Studies" (1997) 10 J. Refugee Stud. 349, 356. For more discussion of the history of thePal estinians in Lebanon and Lebanese attitudes towards them, see Said, supra note 40 at 320-24, 341- 44 .

56. It is often argued that the Arab countries keep the refugees in a state of misery to make Israel look bad. Aside from being a simplistic argument devoid of legal basis, such a contention ignores the complex political and factual characteristics of each of the host countries. The experience of the refugees in Lebanon, Syria, and Jordan, respectively, to a great degree mirrors each country's history, demography, and social and political evolution since 1948. To argue that these states, to name the most obvious, have somehow colluded to "make Israel look bad" is to argue that there has been a kind of comprehensive strategy vis-à-vis the refugees that each country has implemented. Even readers with only a mild background in the history of the modern M iddle East know that such an assertion finds no support in the region's recent past and present.

57. J. M assad, "On Zionism and Jewish Supremacy," N ew Politics (Winter 2002) at 95.

58. The purpose of this paper is not to engage in a lengthy legal discussion of the right of return and the applicability of UN GA Res. to Israel, since many human rights and international legal scholars have al ready undertaken such studies in detail. See, e.g., G.J. Boling, "The 1948 Palestinian Refugees and the Individual Right of Return: An International Law Analysis," accessible online: <http:// www.badil.org/Publications/Legal_ Papers/RoR48.pdf> (dateaccessed: 10February2003); J. Quigley, "Displaced Palestinians and a Right of Return" (1998) 39 Harv. Intl. L. Journal 171; see also Human Rights Watch, "Policy on the Right to Return," online: <http://www.hrw. org/ campaigns/israel/return> (date accessed: 10 February 2003).

59. GA Res. 194, UN GAOR, $3^{\text {rd }}$ Sess., UN Doc. A/810, at 24 (1948).

60. S. Akram, "Reinterpreting Palestinian Refugee Rights Under International Law," in N. Aruri, ed., Palestinian Refugees: The Right of Return (Sterling, Va: Stylus, 2001), at 190 n. 67.

61. Supra note 59 .

62. A kram, supra note 14 at $41-42$.

63. GA. Res. 3236, UN GAOR, $24^{\text {th }}$ Sess., UN Doc. A/Res/3236 (1974).

64. GA Res. 273 (1949) GA Res 273(III) 11 May 1949; see also Boling, supra note 58 at $14 \mathrm{n}$. 39. It is also important to note that at the time Resolution 194 was passed, the principle of the right of return had already found acceptance in customary international law, which is by its nature binding on all states. See Boling, supra note 58 at 10-14, 48.

65. "Clinton Makes Appeal for Kosovar Relief Donations," on CNN.com, April 15, 19990; online: <http://www.cnn.com/ US/9904/05/us.refugees.02/> (date accessed: 10 February 2003).

66. Id.

67. Case of Loizidou v. Turkey, Application No. 40/1993/435/514, European Court of Human Rights, J udgment of N ovember 28, 1996; see also A. El Fassed, "Loizidou v. Turkey: A Precedent for Palestinian Refugees?" available online: <http://www. palestinecenter.org/cpap/pubs/20010223ib.html> (date accessed: 10 February 2003).

68. Case of Cyprusv. Turkey, Application N o. 25781/94, European Court of Human Rights, Judgment of May 10, 2001, at $\mathrm{H}$ olding §III.

69. A kram, supra note 14 , at 46 .

70. Geneva Convention Relating to theProtection of Civilian Persons in the Time of War, 12 August 1949, art. 40, 6 U.S.T. 3516, 75 U.N.T.S. 287. 
71. U niversal Declaration of H uman Rights, arts. $13(2) \& 17(2), G A$ Res. 217A, UN GAOR, $3^{\text {rd }}$ Sess., UN Doc. A/810 (1948).

72. S. Abu-Sitta, "The Right of Return: Sacred, Legal, Possible," in N. Aruri, ed., supra note 60 at 195-207.

73. Id. at 200.

74. I. Pappe, "Israeli Perceptions of the Refugee Question," in N. Aruri, ed., supra note 60 at $71-76$.

75. W.T. M allison \& S.V. M allison, The Palestine Problem in International Law and World Order (London: Longman, 1986) at 186.

76. U. Avnery, "Israel: the Jewish Demographic State," Counterpunch (11 October 2002), available online: <www.counterpunch.org/avnery1011.html> (date accessed: 10 February 2003).

77. For a discussion of thistopic, seeSaid, supra note40, at 351-54.

78. Y. Arafat, "The Palestinian Vision of Peace" N ew York Times (3 February 2002), O pEd at D15.

79. A. Eldar, "A H ard Bargain about Rights" Ha'aretz (13 February 2002); also Ran Edelist, "Ami Ayalon's Practical Wisdom" Ha'aretz (17 September 17 2002); both available online: <http://www.haaretzdaily.com/hasen/ pages/arch/ArchSearch Eng Art.jhtml> (date accessed: 10 February 2003).

80. A. Eldar, "M arwan Barghouti's N ew Year's Wishes" H a'aretz (5September 5 2002), availableonline: <http://www. haaretzdaily.com/hasen/pages/arch/ArchSearchEng Art.jhtml (date accessed: 10 February 2003).

81. A. Eldar, "A Time for Testing, and a Testing Time" Ha'aretz (6 February 2003), available online: <http://www.haaretzdaily.com/hasen/pages/arch/ArchSearch Eng Art.jhtml> (date accessed: 10 February 2003). At this point, I think it important to stress that the remnants of the nearly defunct Palestinian Authority - a deeply unpopular entity that, at the very least, does not enjoy a mandate to negotiate on behalf of the refugees outside the W est Bank and Gaza, if any, for that matter - are in no position to bargain away a right as fundamental and inalienable as the right of return.

82. A. Benn, "Israel Criticizes Draft Palestinian Constitution" Ha'aretz (4 M arch 2003), available online: <http://www.haaretzdaily.com/hasen/pages/arch/ArchSearchEng Art.jhtml (date accessed: 10 February 2003).

Wadie Said is an attorney at the law firm of Debevoise \& Plimpton in N ew York City. A 1999 graduate of Columbia Law School, he has served as a law clerk to the $\mathrm{H}$ on. Charles P. Sifton of the U nited States District Court-EDNY and as an articles editor of the Columbia H uman Rights Law Review, and has authored several legal studies on Palestinian refugees. 